United States Department of Energy

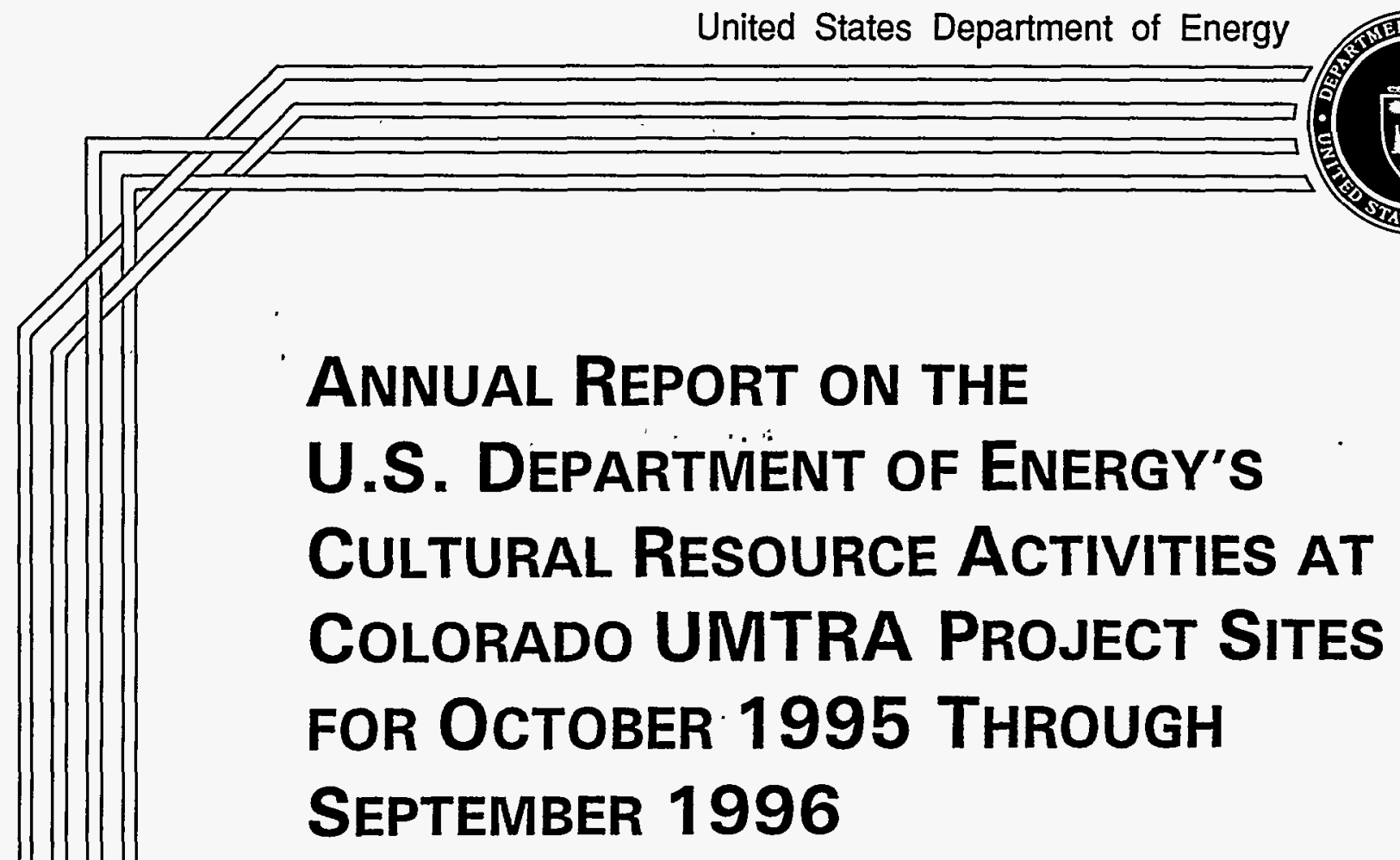

September 1996

RECEIVES

Nov 051996

OSTI

Uranium Mill Tailings Remedial Action Project 


\title{
ANNUAL REPORT ON THE U.S. DEPARTMENT OF ENERGY'S CULTURAL RESOURCE ACTIVITIES AT COLORADO UMTRA PROJECT SITES FOR OCTOBER 1995 THROUGH SEPTEMBER 1996
}

\section{September 1996}

\author{
Prepared for \\ Advisory Council on Historic Preservation \\ Colorado State Historic Preservation Officer
}

and the

U.S. Department of Energy

Environmental Restoration Division

UMTRA Project Team

Albuquerque, New Mexico

\author{
Prepared by \\ Jacobs Engineering Group Inc. \\ Albuquerque, New Mexico
}

\section{DISCLAIMER}

\begin{abstract}
This report was prepared as an account of work sponsored by an agency of the United States Government. Neither the United States Government nor any agency thereof, nor any of their employees, makes any warranty, express or implied, or assumes any legal liability or responsibility for the accuracy, completeness, or usefulness of any information, apparatus, product, or process disclosed, or represents that its use would not infringe privately owned rights. Reference herein to any specific commercial product, process, or service by trade name, trademark, manufacturer, or otherwise does not necessarily constitute or imply its endorsement, recommendation, or favoring by the United States Government or any agency thereof. The views and opinions of authors expressed herein do not necessarily state or reflect those of the United States Government or any agency thereof.
\end{abstract}




\section{DISCLAIMER}

Portions of this document may be illegible in electronic image products. Images are produced from the best available original document. 


\section{TABLE OF CONTENTS}

Section

Page

1.0 INTRODUCTION.............................................................................. $1-1$

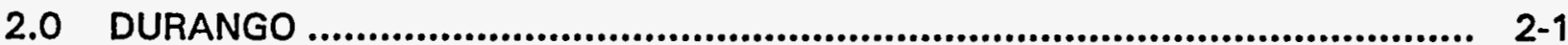

2.1 Cultural Resource Activities .......................................................... 2-1

2.2 Historic Building Inventory Records.............................................. 2-1

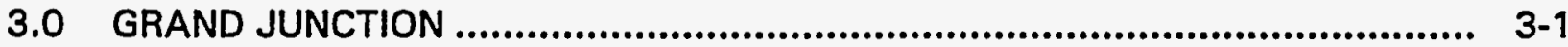

3.1 Cultural Resource Activities ........................................................... 3-1

3.2 Historic Building Inventory Records............................................... 3-1

4.0 GUNNISON........................................................................... 4-1

4.1 Cultural Resource Activities ............................................................. 4-1

4.2 Historic Building Inventory Records............................................... 4-1

5.0 MAYBELL.............................................................................. $5-1$

5.1 Cultural Resource Activities .......................................................... 5-1

5.2 Historic Building Inventory Records................................................ $5-1$

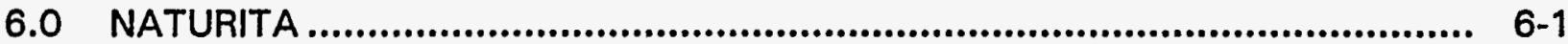

6.1 Cultural Resource Activities ............................................................ 6-1

6.2 Historic Building Inventory Records................................................ $6-4$

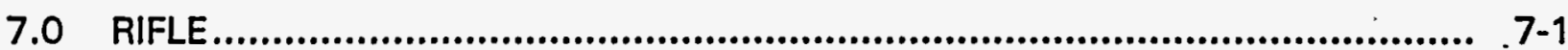

7.1 Cultural Resource Activities ........................................................ 7-1

7.2 Historic Building Inventory Records............................................... 7-1

8.0 SLICK ROCK.............................................................................. $8-1$

8.1 Cultural Resource Activities ........................................................ 8-1

8.2 Historic Building Inventory Records ................................................ 8-2

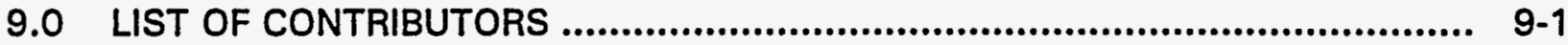

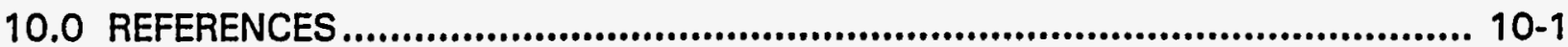




\section{LIST OF FIGURES}

\section{Figure}

Page

5.1 Cultural resources surveys, Maybell, Colorado, site

$5-2$

6.1 Survey area locations, Naturita, Colorado, processing site.............................. 6-2

6.2 Map of tested sites locations, Naturita, Colorado, UMTRA Project site .............. 6-3 


\section{LIST OF ACRONYMS}

Acronym

DOE

EA

EIS

FONSI

HBIR

NRHP

PMOU

SHPO

UMTRA

VP

\section{Definition}

Department of Energy

environmental assessment

environmental impact statement

finding of no significant impact

Historic Building Inventory Records

National Register of Historic Places

programmatic memorandum of understanding

State Historic Preservation Officer

Uranium Mill Tailings Remedial Action

vicinity property 


\section{CHANGE HISTORY}

\begin{tabular}{lll}
\hline Document version & Date & Pages/comments \\
\hline Rev. 0, Ver. 1 & $9 / 24 / 96$ & Initial version. \\
\hline
\end{tabular}




\subsection{INTRODUCTION}

This report summarizes the results of cultural resource activities conducted by the U.S. Department of Energy (DOE) at Uranium Mill Tailings Remedial Action (UMTRA) Project sites in Colorado for the period of October 1, 1995 through September 30, 1996. The inactive uranium mill tailings sites in Colorado are at Durango, Grand Junction, Gunnison, Maybell, Naturita, Rifle, and Slick Rock.

On December 6, 1984, the DOE, the Advisory Council on Historic Preservation, and the Colorado State Historic Preservation Officer (SHPO) entered into a programmatic memorandum of understanding (PMOU) (DOE, 1984). This PMOU requires the DOE to fulfillment of its obligations under various state and federal regulations for the protection and preservation of cultural resources. This report provides the state of Colorado with an annual report on the cultural resource activities performed for all UMTRA Project sites in Colorado.

Due to the completion of surface activities at the UMTRA Project sites, this will be the last annual report to the state of Colorado. Cultural resources activities subsequent to this report will be reported to the state through site-specific correspondence. 


\subsection{DURANGO}

The final environmental impact statement (EIS) for the Durango UMTRA Project site was published in October 1985 (DOE, 1985). The remedial action selected was to relocate all contaminated materials by truck to the Bodo Canyon disposal site. Remedial action began in 1987 and was completed in 1990.

\section{$2.1 \quad$ CULTURAL RESOURCE ACTIVITIES}

Remedial action at the Durango UMTRA Project site was completed in 1990. No cultural resource activities were conducted from October 1995 to September 1996 and no future activities are anticipated.

\subsection{HISTORIC BUILDING INVENTORY RECORDS}

Remedial actions for the vicinity properties (VP) associated with the Durango site have been completed. No additional Historic Building Inventory Records (HBIR) are anticipated for this UMTRA Project site. 


\subsection{GRAND JUNCTION}

The final EIS for the Grand Junction UMTRA Project site was published in December 1986 (DOE, 1986). The remedial action selected was to relocate all contaminated materials by train and truck to the Cheney disposal site. Remedial action began in 1991, and cleanup of the Grand Junction processing site was completed in 1994. Cleanup of the Grand Junction vicinity properties (VP) is expected to be completed in 1998; the Cheney disposal site will remain open to receive contaminated materials from the VPs.

\subsection{CULTURAL RESOURCE ACTIVITIES}

Remedial action cultural resource activities at the Grand Junction UMTRA Project site were completed in 1990. No cultural resource activities were conducted from October 1995 to September 1996 and no future activities at the processing site are anticipated. VP activities will continue to be monitored for cultural resources.

\subsection{HISTORIC BUILDING INVENTORY RECORDS}

Seven buildings over 50 years old were identified in Fiscal Year 1996. All were exempted from review by SHPO (MACTECH, 1996).

\begin{tabular}{|l|l|c|c|}
\hline \multicolumn{1}{|c|}{ DOE ID No. } & \multicolumn{1}{c|}{ Address } & Submitted & Year Built \\
\hline GJ-01042-RS & 938 White Avenue & $03-15-96$ & 1900 \\
\hline GJ-3760-RS & 834 Elm Avenue & $02-02-96$ & 1937 \\
\hline GJ-06361-MR & 2303 North 1st Street & $11-17-95$ & 1888 \\
\hline GJ-06362-RS & 2227 North 1st Street & $01-25-96$ & 1922 \\
\hline GJ-06559-RS & 1223 North 7th Street & $10-06-95$ & 1910 \\
\hline GJ-10886-RS & 227 Belford Avenue & $09-26-95$ & 1940 \\
\hline GJ-14639-MR & 3142 F Road & $11-15-95$ & 1921 \\
\hline
\end{tabular}




\subsection{GUNNISON}

The final environmental assessment (EA) for the Gunnison UMTRA Project site was published in 1992 (DOE, 1992). The remedial action selected was to relocate all contaminated materials by truck to the Landfill disposal site. Remedial action began in 1992 and should be completed in December 1995.

\subsection{CULTURAL RESOURCE ACTIVITIES}

As recorded in the. 1994 through 1995 annual report, prehistoric cultural resources site 5GN2556, an open campsite, was recorded in April 1995 at the Panaview Pit. The site had been distributed in 1996 during excavations at the pit. The site was evaluated in the field as eligible for listing in the National Register of Historic Places (NRHP). It was recommended that the disturbed portions of the site be salvaged and that the remainder of the site be avoided (GRI, 1995A).

A draft treatment plan for archaeological site 5GN2556 at the Panaview Borrow Area, was submitted to DOE and is being modified in response to DOE's comments. The plan will be forwarded to the landowner for concurrence, and if concurrence is received, it will be sent to the SHPO for concurrence (MKFerguson, 1996).

\subsection{HISTORIC BUILDING INVENTORY RECORDS}

No HBIRs for Gunnison VPs were submitted during the period of record. 


\subsection{MAYBELL}

A finding of no significant impact (FONSI) for the Maybell UMTRA Project site was published in 1994 (DOE, 1994a). The final EA for the Maybell site also was published in 1994 (DOE, 1994b). The proposed remedial action was to stabilize all the contaminated materials at the location of the existing tailings pile. Remedial action began in 1995 and is expected to be completed in late 1996.

\section{$5.1 \quad$ CULTURAL RESOURCE ACTIVITIES}

In April 1996, the adjacent property block survey of the main access road was completed by Grand River Institute. No prehistoric sites were discovered, apparently due to the adjacent tree ridges that provided a more attractive camping locality. The survey area had been previously disturbed by erosion, road construction and ranching activities (GRI, 1996a).

On August 15, 1996, Grand River Institute conducted a shovel test excavation of site 5MF3932, a prehistoric open camp (Figure 5.1). Results of the site testing indicate the site contains significant undisturbed prehistoric cultural deposits. A temporary road realignment around site 5MF3932 has been surveyed for use by the trucks transporting residual radioactive material from near the Yampa River (GRI, 1996b).

\subsection{HISTORIC BUILDING INVENTORY RECORDS}

There are no known historical buildings or structures associated with the Maybell site; therefore, no HBIRs are anticipated for this UMTRA Project site. 


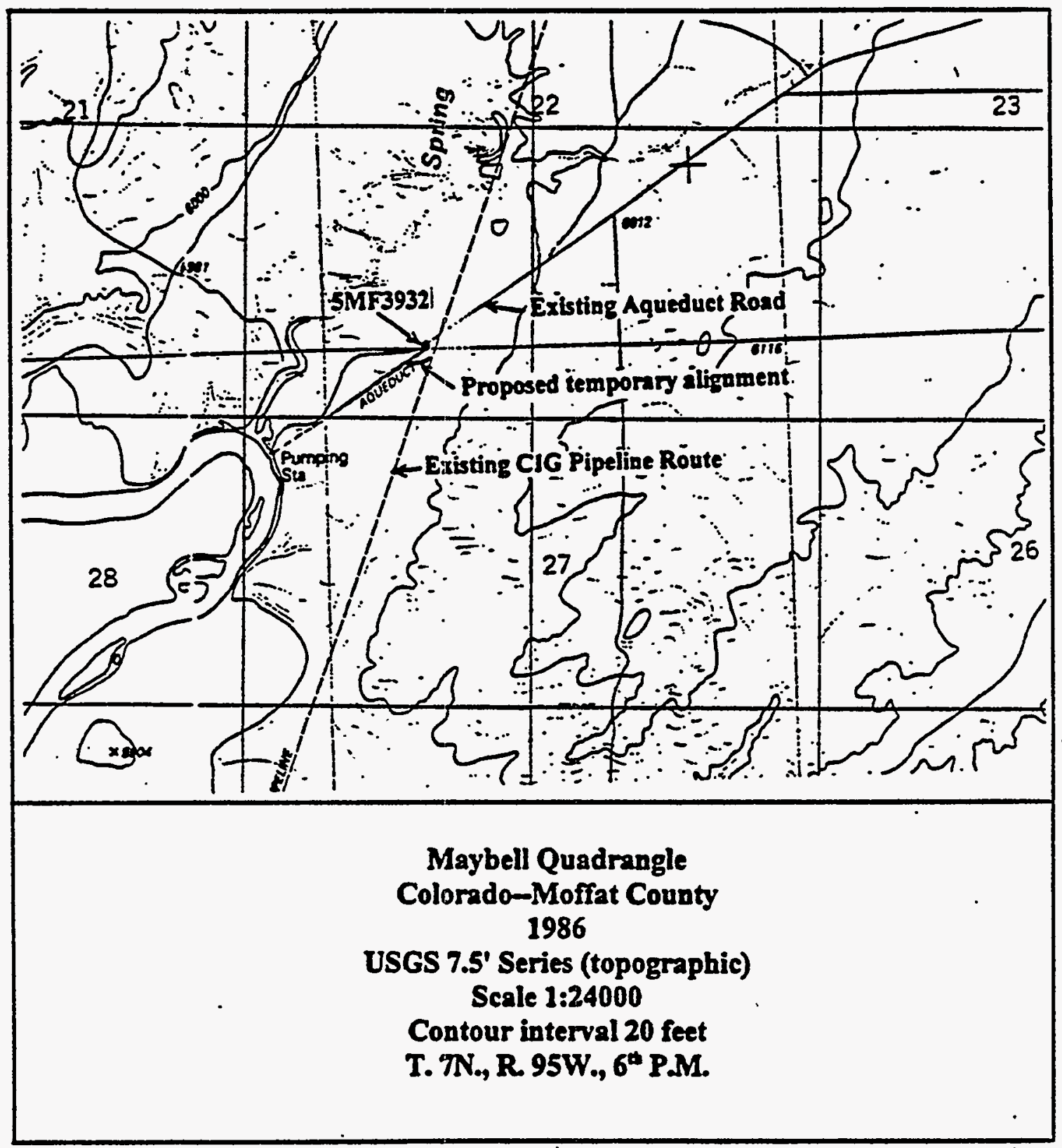

REF: GAI, $1996 b$.

FIGURE 5.1

CULTURAL RESOURCE SURVEYS MAYBELL, COLORADO, SITE 


\subsection{NATURITA}

The final EA and FONSI for the Naturita UMTRA Project site were published in 1994 (DOE, 1994c; 1994d). The proposed remedial action was to relocate all of the contaminated materials by truck to the Uravan Project disposal site. Existing structures at the Naturita processing site were demolished in 1994. The remainder of the remedial action is scheduled to begin in 1996 and to be completed in 1997.

\subsection{CULTURAL RESOURCE ACTIVITIES}

Due to the change of the proposed disposal site from the Dry Flats area to the Uravan disposal site, DOE requested the Colorado SHPO to concur on DOE's determination that disposal at the site would not effect historic properties. On April 8, 1996, the Colorado SHPO Officer concurred with DOE (CHS, 1996).

A Class III cultural resource inventory of approximately 50 acres (20.2 ha) was carried out for several windblown contaminated areas along the San Miguel River valley and the upper Burbank disposal site and adjacent Club Mesa borrow areas above Uravan (Figure 6.1). All are privately owned. These areas may be affected by the Naturita UMTRA Project near Naturita and Uravan, Montrose County, Colorado. The survey was undertaken on April 1 and 4, 1996. Because of the disturbed nature, only a small area was surveyed at the upper Burbank and Club Mesa location.

One new site (5MN4679) was recorded and one previously-recorded site (5MN3037) was reevaluated during the inventory. All of the sites consisted of lithic scatters of unknown age or cultural affiliation. Site 5MN3037 has been recommended as possibly eligible for nomination to the NRHP based on additional site area and materials recorded during the present survey. Due to the site disturbance from field clearing and plowing, testing is recommended to determine whether intact subsurface deposits or features are still intact. Site $5 \mathrm{MN} 4679$ has been recommended as not eligible for nomination to the NRHP (CASA, 1996a).

In May of 1996 archaeological testing at two additional sites was conducted (Figure 6.2). The sites tested were in areas where windblown contaminants will be cleaned up from sites on private land. Testing was designed to evaluate the sites potential for nomination to the NRHP.

Site $5 \mathrm{MN} 3036$ was partially on private land and primarily located on BLM land. The small portion of this site on private land that will be impacted by the cleanup, does not contain subsurface cultural remains. This portion of believed to be a noncontributing part of the site that is recommended as not eligible. The BLM portion will not be impacted by the Naturita UMTRA Project. Based on these negative findings, there should be no effect to the integrity of the site. The majority of the site will remain intact, and it is recommended that the site is eligible for nomination to the NRHP. Additional recommendations are made to 


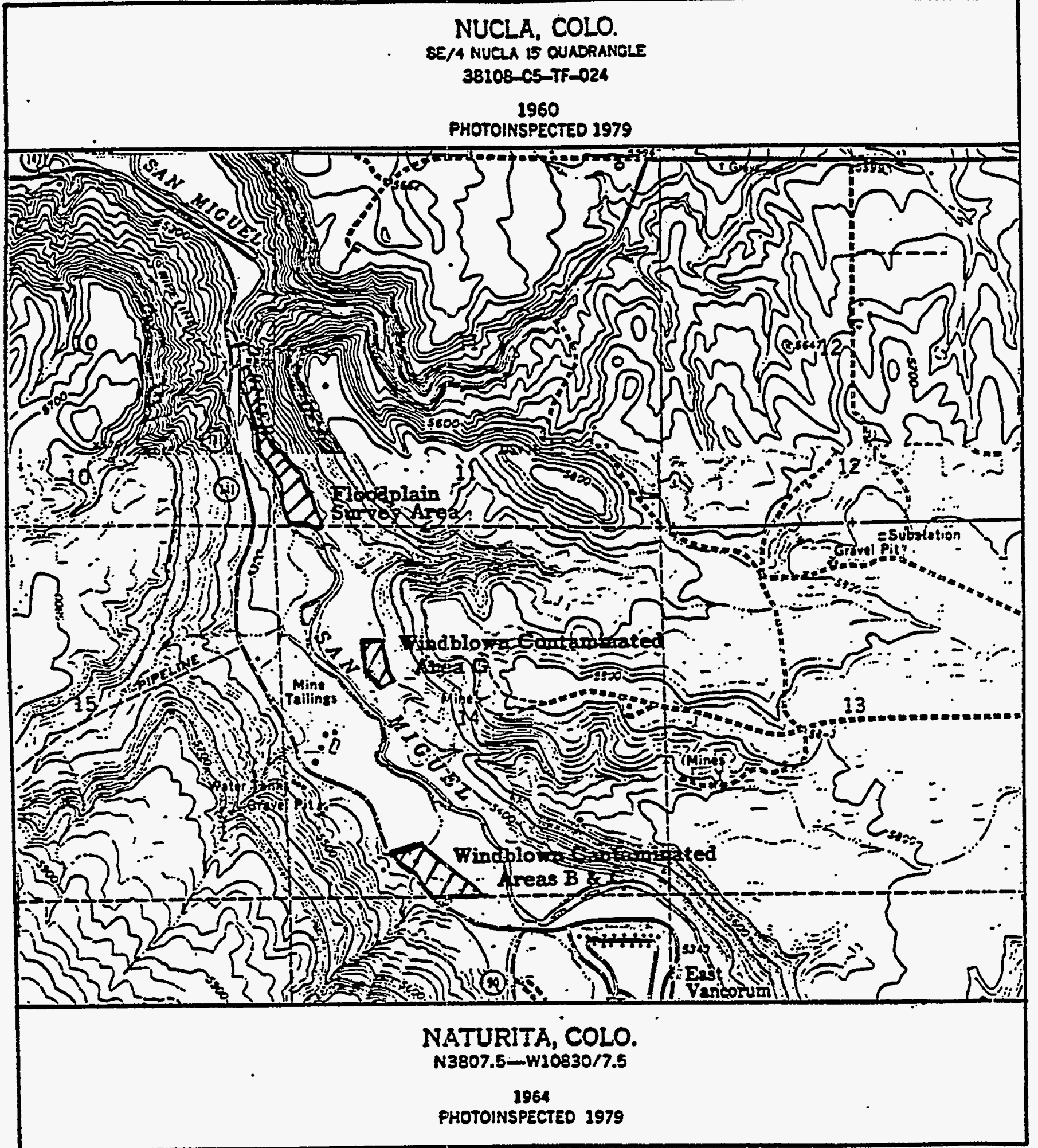

FIGURE 6.1

SURVEY AREA LOCATIONS

NATURITA, COLORADO, SITE 


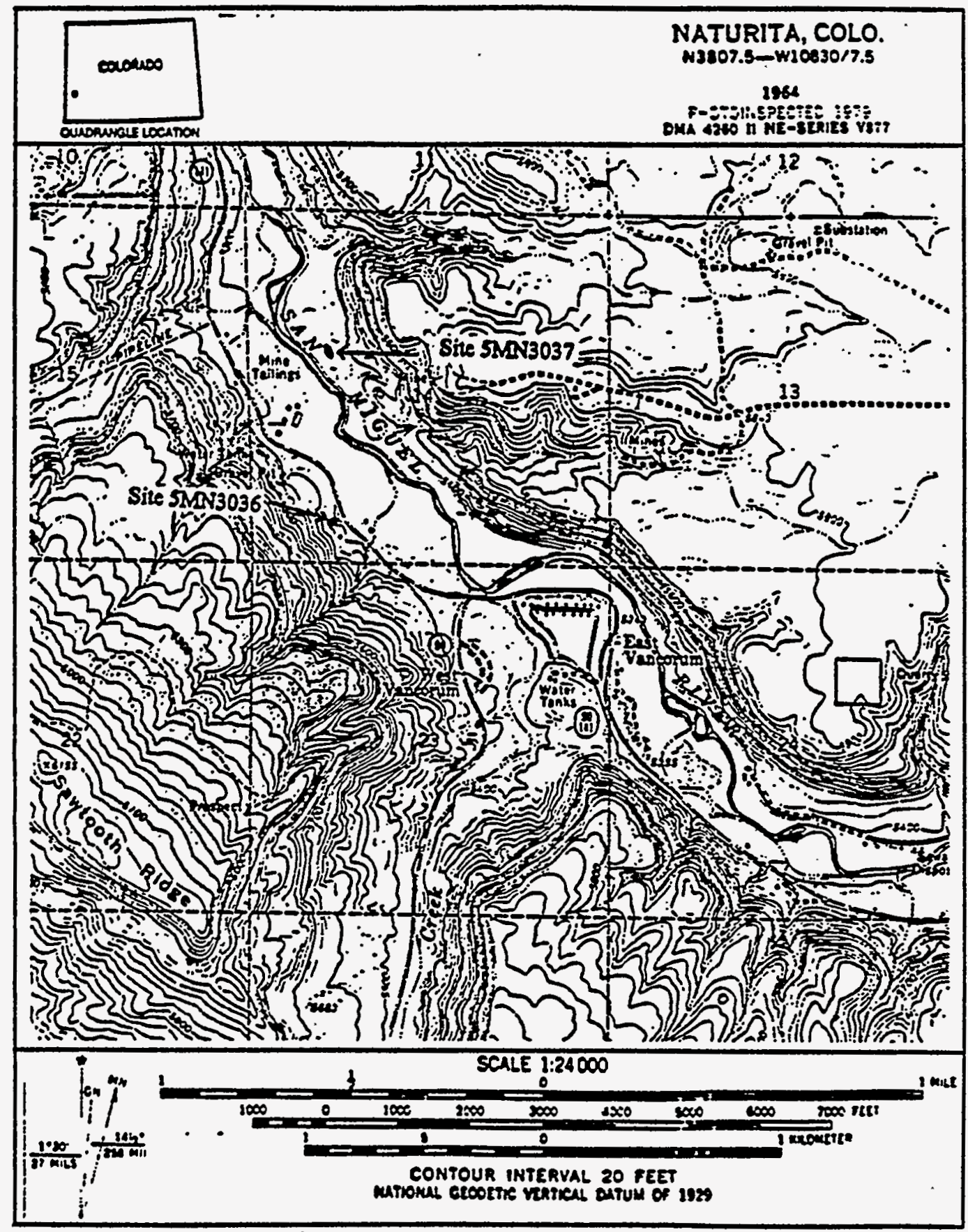

AEF: CASA, 1905b.

\section{FIGURE 6.2 \\ MAP OF TESTED SITES LOCATIONS NATURITA, COLORADO, SITE}


fence or flag the BLM portion of the site during contaminated soil removal to assure no inadvertent damage occurs to the remainder of the site.

Site $5 \mathrm{MN} 3037$ showed that the two loci had been damaged by plowing and the integrity of the site was seriously altered. Testing revealed no intact subsurface features or deposits with dateable materials, and the research potential of this site has been exhausted. Based on the negative findings, it is recommended that this site is not eligible for nomination to the NRHP and no further work is recommended (CASA, 1996b).

6.2 HISTORIC BUILDING INVENTORY RECORDS

No HBIRs for Naturita VPs were submitted during the period of record. 


\subsection{RIFLE}

The final EIS (DOE, 1990) and Record of Decision (56 FR 2166) for the Old and New Rifle UMTRA Project sites was published in March 1990. The selected remedial action was to relocate all of the contaminated materials by truck to the Estes Gulch disposal site. Remedial action began in 1992 was completed in 1996.

\subsection{CULTURAL RESOURCE ACTIVITIES}

No cultural resource activities were conducted for the Old Rifle and New Rifle, and Estes Gulch UMTRA Project sites during the period October 1995 through September 1996.

\subsection{HISTORIC BUILDING INVENTORY RECORDS}

No HBIRs for Rifle VPs were submitted during the period of record. 


\subsection{SLICK ROCK}

The final EA and FONSI for the North Continent and Union Carbide Slick Rock UMTRA Project sites were published in 1995 (DOE, 1995b; 1995c). The proposed remedial action was to relocate all of the contaminated materials by truck to the Burro Canyon disposal site. The remedial action began in 1995 and is scheduled to be completed in late 1996.

\subsection{CULTURAL RESOURCE ACTIVITIES}

In March and April of 1996 Durango Archaeological Consultants conducted monitoring, surface documentation, and surface collection at three archaeological sites in the areas of the Slick Rock sites, UMTRA Project Area, San Miguel County, Colorado. Additional rock art documentation was conducted (Site 5SM1941), surface collection of a sample of a small lithic scatter was accomplished (5SM1942), and surface documentation and monitoring of contaminated materials removal from the historic Poulet and Vollique Mill site occurred (5SM1944) (CASA, 1996c).

Detailed recording at 5SM1941 indicated that additional graffiti had been added to the petroglyph panel in the last nine years since it's initial recording. Recommendations for this as a site not eligible for nomination to the NRHP has not changed.

Site 5SM1942, a sparse lithic scatter, was determined in consultation with the Colorado SHPO to be not eligible for inclusion in the NRHP. Following recommendations by the BLM a sample of the lithics on this site was collected, and a more detailed analysis of the surface artifacts was undertaken. A more detailed record of the site now exists, but it's status as a non-eligible site to the NRHP has not changed.

Monitoring of contaminated tailings removal from Site 5SM1944 proved that the site was the location of the historic Poulet and Vollique Mill. Limited structural remains, radioactive materials, and historic artifacts indicated a crude laboratory was present in association with the mill which was in operation from 19011904. The historic and Ute petroglyphs also found at the site were protected through the placement of protective fencing prior to earth moving activities.

The site was initially determined to be eligible to the NRHP based on the unique Ute petroglyphs present, but additional significance for the site is derived from the later historic mill remains. The mill was one of the first uranium processing facilities in southwest Colorado, and may have been one of the first such operations in the United States. Unfortunately, the mill was highly radioactive from the early processing activities so this portion of the site was not preserved, and were removed with the remainder of the contaminated materials at the site. A portion of the contaminated materials at this site extended beneath an active gas pipeline and could not be removed during the removal project. In the future if these materials are removed it is recommended that a qualified archaeologist 
be present to monitor the removal. While the mill portion of this site is no longer present, the site is still a significant site because of the presence of the petroglyphs which should be preserved and protected (CASA, 1996c).

In a separate activity, a water line that has been incorrectly installed through an archaeological area at the Burro Canyon site was relocated.

\subsection{HISTORIC BUILDING INVENTORY RECORDS}

No HBIRs for Slick Rock VPs were submitted during the period of record. 


\subsection{LIST OF CONTRIBUTORS}

The following individuals contributed to the preparation of this report.

\begin{tabular}{ll}
\hline Name & Contribution \\
\hline M. Gawthrop Cooper & Author \\
A. Holm, E. Artiglia & Reviewer \\
L. Maez, S. Portlock & Text processing \\
T. Bond & Graphics \\
\hline
\end{tabular}




\subsection{REFERENCES}

CASA (Complete Archaeology Service Associates), 1996a. Cultural Resource Inventory Four Additional Windblown Contamination and Borrow Areas, Naturita UMTRA Project Montrose County, Colorado, UPDCC file location 17.15.4, April 12.

CASA (Complete Archaeology Service Associates), 1996b. Archaeological Testing of Two Sites (5MN3036 and 5MN3037) in the Naturita UMTRA Windblown Contaminant Area, Montrose County, Colorado, UPDCC file location 17.15.4, July 8.

CASA (Complete Archaeology Service Associates), 1996c. Archaeological Investigations at the Slick Rock Uranium Mill Tailings Remedial Site, San Miguel County, Colorado, UPDCC file location 11.15.4, June 4.

CHS (Colorado Historical Society) 1996. Letter to L.A. Woodworth, Uravan and Naturita Title I Disposal Site - Upper Burbank Quarry from James E. Hartman, Colorado Historical Society, UPDCC file location UMT 72679, April 8.

DOE (U.S. Department of Energy), 1996. Letter to Mr. James Hartman, State Historic Preservation Officer, from L.A. Woodworth, U.S. Department of Energy, UPDCC file location 17.15.4, August 20.

DOE (U.S. Department of Energy), 1984. "Programmatic Memorandum of Understanding," No. DE-6M04-84AL28460, prepared by U.S. Department of Energy, UMTRA Project Office, Albuquerque Operations Office, Albuquerque, New Mexico.

GRI (Grand River Institute), 1996a. Limited-Results Cultural Resource Survey Form, completed by Cari E. Conner, UPDCC file location 14.51.4, April 17.

GRI (Grand River Institute), 1996b. Evaluation Testing of Site 5MF3932 for the UMTRA Project at Maybell for MK-Ferguson in Moffat County, Colorado, GRI Project No. 9629, UPDCC file location 14.15.4, August 27.

GRI (Grand River Institute), 1995. "Cultural Resources Inventory, UMTRA Project, Gunnison, Colorado, Three Borrow Areas and One Bio-Stack Pile," GRI Project No. 95322, prepared by GRI, Grand Junction, Colorado, for Ames Construction Company, Gunnison Projects Office, Gunnison, Colorado, UPDCC file location 8.15.4.

MACTECH, 1996. Historic Building Record for Fiscal Year 1996, UPDCC file location 10.15.4.

MK-Ferguson 1996. Treatment Plan for Archaeological Site 5GN2556 at the Panaview Borrow Area, Gunnison, Colorado, UPDCC file location 8.15.4. 
Navajo Nation, 1996. Addendum to Cultural Resource Inventory: Cane Valley Frog Ponds and Old Mill Site Haul Road; Monument Valley UMTRA Project, Navajo Nation, Apache Country Arizona; attachment to letter from Arizona State Parks, UPDCC file location 19.15.4.

\section{FEDERAL REGULATIONS}

56 FR 2166, Compliance with the National Environmental Policy Act: Record of Decision for Remedial Action at the Former Union Carbide Corporation Uranium Mill Sites, Rifle, Garfield County, Colorado, U.S. Department of Energy, January 22, 1991. 